\title{
Hepatitis C Virus: 30 Years after Its Discovery
}

\author{
Michael Houghton \\ Li Ka Shing Applied Virology Institute, Department of Medical Microbiology \& Immunology, Faculty of \\ Medicine \& Dentistry, University of Alberta, Edmonton, Alberta T6G 2E1, Canada \\ Correspondence: michael.houghton@ualberta.ca
}

Evidence for the existence of another hepatitis-causing pathogen, other than the known hepatitis A and B viruses, emerged in the mid-1970s. A frustrating search of 15 years was ended by the identification of the hepatitis $C$ virus in 1989 using a recombinant DNA immunoscreening method. This discovery quickly led to blood tests that eliminated posttransfusion hepatitis $C$ and could show the partial efficacy of type 1 interferon-based therapies. Subsequent knowledge of the viral replication cycle then led to the development of effective direct-acting antivirals targeting its serine protease, polymerase, and nonstructural protein 5A that resulted in the approval of orally available drug combinations that can cure patients within a few months with few side effects. Meanwhile, vaccine strategies have been shown to be feasible, and they are still required to effectively control this global epidemic.

W ith the advent of the discoveries of the hepatitis B virus (HBV) in the 1960s by Baruch Blumberg and colleagues (Bayer et al. 1968) and the hepatitis A virus (HAV) in the early 1970s by Feinstone et al. (1973), it became evident, surprisingly, that most transfusion-associated hepatitis cases were caused by neither of these viral infections (Prince et al. 1974; Feinstone et al. 1975), thus heralding the era of non$\mathrm{A}$, non-B hepatitis (NANBH). In those days of large multiunit blood transfusions and the use of paid blood donors, rather than the use of volunteer blood today, the incidence of posttransfusion NANBH (ptNANBH) could be as high as 5\%-10\% (Hollinger et al. 1980). Initially perceived as a minor disease because of the lack of significant morbidity during the acute phase of infection, it gradually became apparent that this form of hepatitis frequently persisted as a chron- ic condition that could slowly lead to chronic hepatitis and liver cirrhosis, which in turn could lead to end-stage liver disease and hepatocellular carcinoma (Alter 1980). This knowledge ushered in an intense effort to discover the etiological agent(s) that, after a long delay, led to the identification of the hepatitis $\mathrm{C}$ virus (HCV) in 1989.

\section{HCV DISCOVERY}

The basic challenges in identifying HCV were its much lower titer relative to HAV and HBV; the lack of a defined, specific antibody or antigen, which was key to the discovery of HBV (Bayer et al. 1968); the lack of a defined viral morphology evident in the electron microscope, as in the discovery of HAV (Feinstone et al. 1973); and the lack of an in vitro system for propagating

Editors: Arash Grakoui, Jean-Michel Pawlotsky, and Glenn Randall

Additional Perspectives on Hepatitis C Viruses: The Story of a Scientific and Therapeutic Revolution available at www.perspectivesinmedicine.org

Copyright (C 2019 Cold Spring Harbor Laboratory Press; all rights reserved; doi: 10.1101/cshperspect.a037069

Cite this article as Cold Spring Harb Perspect Med 2019;9:a037069 
M. Houghton

virus, which was instrumental in the discovery of HIV (Barré-Sinoussi et al. 1983). Our work also predated the routine use of the powerful polymerase chain reaction (PCR) nucleic acid amplification technology.

Starting in 1982, my laboratory at the Chiron Corporation used blood samples from patients diagnosed with NANBH, as well as liver tissue obtained from autopsies of NANBH patients provided by Tatsuo Miyamura from the Japanese National Institutes of Health (NIH). Quickly realizing that the quality of nucleic acid extracted from autopsied liver tissue was poor, we sought a collaboration with Dan Bradley of the Centers for Disease Control and Prevention (CDC) who was using the chimpanzee model for NANBH (Bradley et al. 1979) and who could provide fresh samples of blood and liver biopsies yielding intact nucleic acid. Much of our work was focused on using recombinant DNA methods to identify a cloned cDNA derived from a viral mRNA or genome present in NANBH tissue that was absent from control tissue using highly radioactive hybridization probes made from each tissue (+/- hybridization probes). Although this was successful at identifying many interesting genes clearly modulated by NANBH infection, no viral clones could be identified after several years of effort. This led us to request (and cofund) the CDC to determine the infectious titer of chimpanzee samples in an effort to produce samples equivalent to that of the NIH's patient $\mathrm{H}$ plasma determined in $~ 1980$ to have a chimpanzee infectious titer of $10^{6.5}$ per $\mathrm{mL}$ $\left(\mathrm{CID}^{50} / \mathrm{mL}\right.$ ) (Feinstone et al. 1981). This led to Dan eventually supplying us with chimpanzee plasma of $\sim 10^{6} \mathrm{CID} / \mathrm{mL}$ as well as liver tissue samples from such animals. Unfortunately, we were still unable to identify viral clones with these samples using +/- hybridization probe methods or using hybridization probes derived from the known HBV, HDV, picornaviral, togaviral, and flaviviral genomes. In addition, many other attempts using these materials to produce viral-specific monoclonal antibodies, to identify a large viral genome by silver staining of electrophoresis gels, to identify a viral reverse transcriptase activity, and to produce a virus-propagation cell culture system all failed along with addition- al approaches. The main contributors in my laboratory in this time-consuming and frustrating work were Qui-Lim Choo, Amy Weiner, and Kangsheng Wang with invaluable support and guidance from Lacy Overby, who had previously pioneered the introduction of HAV and HBV diagnostics while at Abbott Laboratories.

In late 1985 and early 1986, in addition to continuing with most of the above approaches, we also started a new approach involving immunoscreening cDNA libraries made from NANBH-infected chimpanzee livers and plasma using NANBH patient sera as a presumptive source of virus-specific antibodies. Although this approach did not always work even when using very well defined antibodies and despite the known chronicity of NANBH suggesting a poor immune response, I decided to try what hitherto I and many others had considered a very risky approach (indeed, many illustrious members of our science advisory board recommended against this approach). George Kuo in the neighboring laboratory to mine working on Factor 8 characterization was an ardent enthusiast of this approach and he was largely responsible for stimulating me to try it. Dan Bradley was also a supporter of this strategy and was already providing chimpanzee samples to another group using this approach in a separate and independent collaboration.

Initially, I prepared cDNA libraries from poly $(\mathrm{A})^{+}$mRNA from four NANBH-infected chimpanzee livers in the lambda gt11 phage. The latter had been developed at Stanford to enable high-throughput cDNA immunoscreening (Young and Davis 1983). George optimized the detection methods using $\mathrm{I}^{125}$-radiolabeled antihuman Ig and Qui-Lim carefully screened many millions of clones, but none of the positives could be proven to be of viral origin. Next, I made a random-primed gt11 cDNA library extracted from NANBH-infected chimpanzee plasma based in part on Dan's proposal that the NANBH agent could possibly be flavi- or toga-like, and toga-like agents as classified at that time were known not to possess poly $(\mathrm{A})^{+}$ tails. Again, however, no viral clones could be identified from Qui-Lim's screening. In making another cDNA library from NANBH-infected 
chimpanzee plasma derived from both extracted RNA and DNA (not knowing what the elusive viral genome comprised), I encountered severe problems with the aqueous nucleic extract forming a viscous gelatinous layer. Almost on the point of discarding this extract, I persisted in making the cDNA library with little expectation of success and Qui-Lim screened it with his usual exceptional care, this time using serum derived from a chronically infected NANBH patient. This patient displayed an unusually high serum alanine aminotransferase level indicative of unusually severe chronic NANBH. We thought that perhaps this patient may have higher levels of circulating viral antibodies. Previously, we had mainly used serum from convalescent humans and chimpanzees (we now know that chronic HCV patients have higher levels of anti-HCV antibodies than individuals who have spontaneously resolved their acute infections).

Qui-Lim found five positive clones. Intriguingly, a couple were derived from the small amounts of MS2 phage RNA that I had added to the plasma extract as carrier meaning that this patient had antibodies to this bacteriophage, an example of the power of this immunoscreening approach. Two other clones were derived from the chimpanzee genome, leaving one, named clone 5-1-1 by Qui-Lim, as the one remaining candidate for a NANBH viral origin. Almost unbelievably, after nearly 5 years of searching full-time for the etiological agent of NANBH, we were able to show the following:

1. The 5-1-1 encoded antigen bound to the majority of human NANBH sera tested but not to control human sera.

2. 5-1-1 and overlapping clones were not derived from the chimpanzee or human genome using Southern blot analyses.

3. 5-1-1 was derived from a single-stranded RNA molecule that directly encoded the immunoreactive antigen (and was therefore positive-stranded).

4. Clone 5-1-1 was derived from a large $\left(\sim 10,000\right.$ nucleotides) poly $(\mathrm{A})^{+}$RNA genome found only in $\mathrm{NANBH}$-infected chimpanzee livers but not in control liver samples.

5. Blood recipients from the Kansas City blood bank undergoing acute posttransfusion NANBH seroconverted to anti-5-1-1 antibody;

6. Chimpanzees experimentally infected with NANBH by Dan seroconverted to anti-5-11 antibody, whereas his animals infected with HAV or HBV did not.

7. The deciphered partial nucleotide sequence of the large RNA molecule encoding clone 5-1-1 was very distantly related to the flaviviruses.

At this point in late 1987, Qui-Lim, George, and myself considered that we had identified the causative agent of blood-borne NANBH (Fig. 1), called it the hepatitis $\mathrm{C}$ virus (HCV), and filed the first of many patent applications. The work was officially published in early 1989 (Choo et al. 1989).

\section{PROTECTING THE BLOOD SUPPLY}

Our next objective was to try to protect the blood supply using a diagnostic based on the C100-3 antigen (encoded by clone 5-1-1 and its immediately adjacent clones). However, we knew that the chronically infected and infectious chimpanzee plasma from which we derived these clones (CDC \#910, otherwise called "Rodney") did not have circulating anti-C100-3 antibodies, whereas another infectious, chronically infected CDC chimpanzee plasma did (chimpanzee "Don"). We therefore next assayed a blinded panel of sera from Harvey Alter of the U.S. NIH containing both proven infectious sera and proven noninfectious control sera. Fortunately, using our prototype anti-C1003 enzyme-linked immunosorbent assay (ELISA), we were able to show the specific detection of anti-C100-3 antibodies in most of the proven infectious samples but not in the noninfectious controls (Kuo et al. 1989). Furthermore, after assaying many different U.S. NANBH patients from Harvey, we were able to detect seroconversion to anti-C100-3 antibodies in most cases along with at least one positive 
M. Houghton

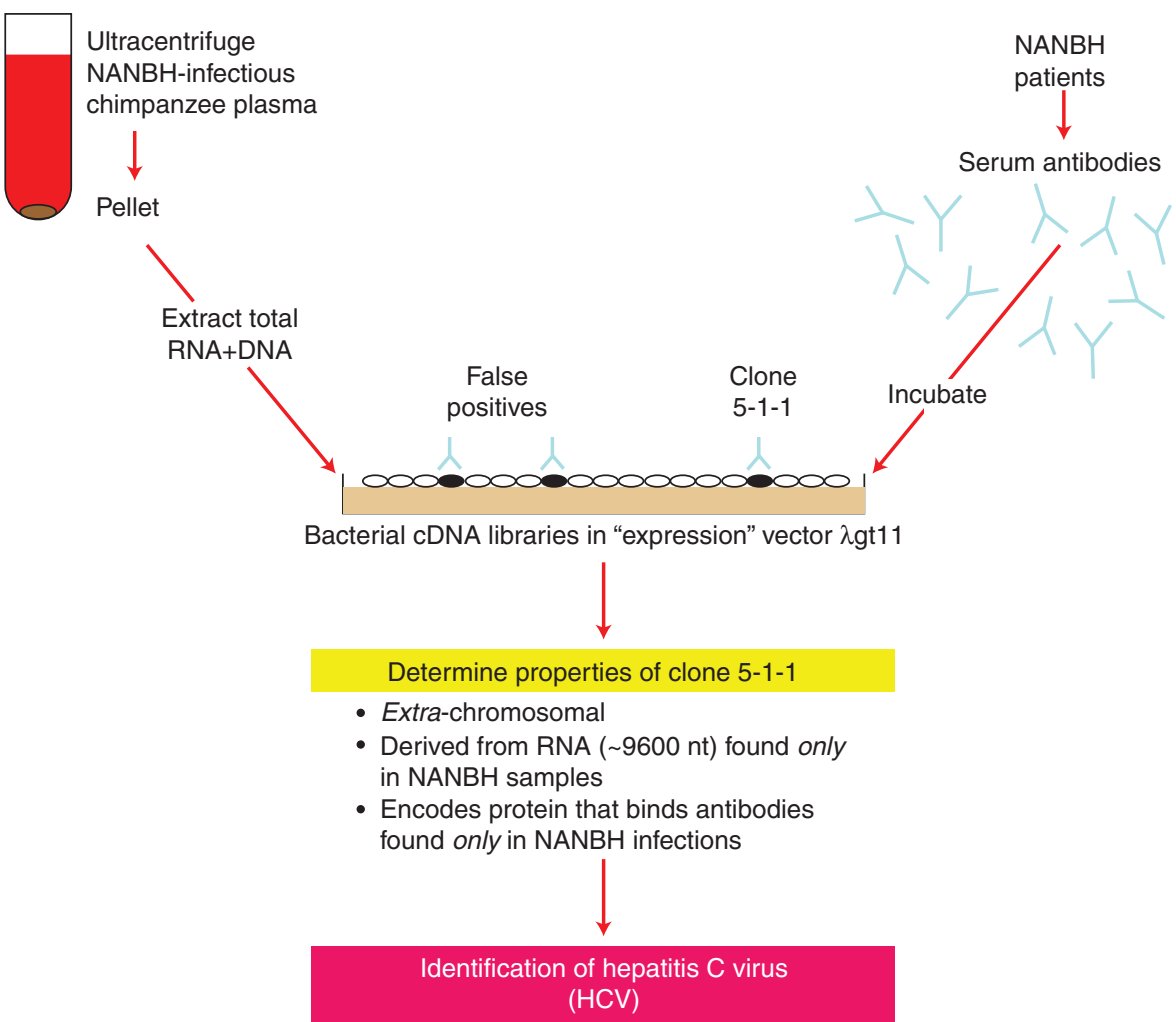

Figure 1. Schematic of identification of the causative agent of blood-borne non-A, non-B hepatitis (NANBH).

blood donor implicated in the majority of these transfusion NANBH cases. Simultaneously, we received other NANBH blood samples from Tatsuo Miyamura in Japan, Ferruccio Bonino and Massimo Colombo in Italy, and Gary Gitnick, Gary Tegtmeier, Al Redeker, Jules Dienstag, Miriam Alter, and Cladd Stevens in the United States, from which we were able to show that anti-C100-3 antibodies were present in most of these chronic cases of NANBH, although their presence was much lower in the early acute phase of infection. This told us that HCV was the major cause of parenteral NANBH around the world (Kuo et al. 1989).

The first commercial test for anti-C100-3 antibodies was approved in Japan in 1989, followed by the United States and other countries in 1990 and later. Meanwhile, we "walked" along the genome of HCV sequencing overlapping clones and discovering additional antibody epitopes that improved the sensitivity of our anti-
HCV detection ELISAs. When combined later with nucleic acid tests detecting the HCV genome using reverse transcription polymerase chain reaction (RT-PCR) and transcription-mediated amplification (TMA) techniques, transfusion-associated hepatitis C was effectively eliminated in those countries that implemented these tests.

\section{KNOWLEDGE OF THE VIRAL LIFE CYCLE LEADS TO THE CURE}

Although type 1 interferon had been shown to be of benefit to some NANBH patients, later improved with the use of pegylated interferon$\alpha$ and the addition of ribavirin, this evolved therapy still often required at least a year of therapy and was associated with significant toxicity. It also cured only $\sim 50 \%$ of patients (McHutchison et al. 2009). Developing new drugs targeting the viral life cycle then became paramount. 
The genomic sequence revealed that it encoded motifs highly conserved among viral polymerases and chymotrypsin-like serine proteases (Choo et al. 1991). Given the successful history of developing drugs to similar targets for HBV and HIV, these became the focus of developing direct-acting antivirals (DAAs) for HCV. Unfortunately, progress was slow because the HCV protease to this enzyme did not have such a highly druggable, defined active site as did HIV. Also, many candidate drugs were ruled out by toxic side effects either in animals or in the clinic. Eventually, first-generation protease inhibitors were approved for human use that significantly improved therapeutic options for patients. Later, more potent and better-tolerated second-generation protease inhibitors became available in 2012 (for review, see de Leuw and Stephan 2018).

Because polymerase inhibitors had formed the cornerstone of therapy for HBV and HIV because of their cross-clade efficacy and high barrier to drug resistance, much effort was expended in developing specific HCV polymerase inhibitors. This eventually translated to the approval of sofosbuvir in 2013, which remains the only approved polymerase inhibitor of $\mathrm{HCV}$ at the time of writing (Sofia et al. 2010). The development of cell-based replicons of $\mathrm{HCV}$ from the leading virology laboratories of Ralf Bartenschlager and Charles Rice not only greatly facilitated gaining a knowledge of the viral life cycle over the next decades but also provided valuable drug screening and drug development tools (Lohmann et al. 1999; Blight et al. 2000).

Highly creative use of these replicons resulted in the discovery of the most potent antivirals ever developed for any virus, the nonstructural protein 5A (NS5A) inhibitor daclatasvir (Lemm et al. 2011). Despite NS5A not being a typical enzyme but essential for viral production, this symmetrical small molecule binds to the natural NS5A dimer to inhibit its action and its oligomerization with high affinity and huge potency. Derivatives of this drug have been developed by various groups, which led to the approval of the combination of ledipasvir and sofosbuvir in 2014 by Gilead (Gane et al. 2014). This cured the large majority of patients after just 1-3 months of therapy and was well-tolerated. A newer duo combination comprising another derivative of daclatasvir (velpatasvir) with sofosbuvir is equally effective against all HCV genotypes (Weisberg and Jacobson 2017). Today, several companies have various all oral, smallmolecule drug combinations approved for human use that cure patients within just 1-3 months of therapy. This spectacular progress represents the first persistent viral infection of man to be curable. A key challenge of the future remains to deliver these currently expensive drugs to all of the 100 million or so estimated global carriers of $\mathrm{HCV}$.

\section{HCV VACCINE}

The history of infectious disease has taught us that effective control of epidemics and their elimination requires the use of sensitive diagnostics (and blood screening tests in the case of blood-borne agents), curative and safe therapeutics, and implementation of effective vaccination. We have had efficient and cheap diagnostics and antibiotics for chlamydia, syphilis, and gonorrhea for many decades but still have epidemics today in the absence of vaccines; the only human virus infection to be eliminated so far is smallpox, which has been accomplished by global vaccination campaigns over many decades. Therefore, the next big challenge for $\mathrm{HCV}$ is to develop a vaccine, and developing at least a partially effective vaccine seems feasible based on the knowledge acquired over the last 20 years.

Protective natural immunity against $\mathrm{HCV}$ has been shown in chimpanzees (Weiner et al. 2001; Lanford et al. 2004) and humans (Mehta et al. 2002), and both cellular (Cooper et al. 1999; Gerlach et al. 1999; Grakoui et al. 2003; Shoukry et al. 2003) and humoral (Lavillette et al. 2005; Pestka et al. 2007; Meuleman et al. 2011; Morin et al. 2012) correlates of immunity have emerged. Earlier concerns about neutralizing $\mathrm{HCV}$ antibodies being isolate-specific have been assuaged by the demonstration of monoclonal antibodies that cross-neutralize the infectivity of most $\mathrm{HCV}$ genotypes that occur around 
M. Houghton

the world (Law et al. 2008; Keck et al. 2016) and also by rodents (Stamataki et al. 2007), chimpanzees (Meunier et al. 2011), and human volunteers (Law et al. 2013) who were vaccinated with the recombinant E1E2 heterodimeric envelope glycoproteins from a single isolate, but who developed broadly cross-neutralizing antibodies including those targeting important discontinuous epitopes formed by the native interaction of E1 with E2 (Wong et al. 2014). Vaccines based on recombinant VLPs or recombinant E2 alone have also been shown to generate some of these cross-neutralizing antibodies (Garrone et al. 2011; Vietheer et al. 2017; Christiansen et al. 2018; Wang et al. 2019).

Interestingly, HCV is associated with highdensity lipopoproteins, which stimulate infection via enhanced interactions with the HCV receptor, SRB1, in turn rendering the virus less sensitive to neutralizing antibodies (Bartosch et al. 2005; Dreux et al. 2006; Voisset et al. 2006). Furthermore, HCV is secreted via the apolipoprotein pathway and is found associated and exchanging with various low-density apolipoproteins, which again reduces the efficacy of neutralizing antibodies via enhancement of virus infection through interaction with cell surface heparan sulfate proteoglycans (Meunier et al. 2005; Yang et al. 2016; Bankwitz et al. 2017). In addition, neutralizing antibodies are slow to appear in infected individuals (Chien et al. 1993; Logvinoff et al. 2004), possibly as a result of its complexed lipoprotein viral structure. By the time high-affinity, cross-neutralizing antibodies appear, the process of immunological exhaustion and anergy of the cellular immune response to the virus may have already occurred (Fuller et al. 2013). Although neutralizing antibodies can still play a protective role in $\mathrm{HCV}$ infection, the above factors may explain why $\mathrm{HCV}$ is such a persistent virus, unlike HAV and $\mathrm{HBV}$, and also encourages vaccine strategies that prime immunological B- and T-cell memory, leading to rapid anamnestic responses following exposure to virus.

It should be noted that assays for HCV-neutralizing antibodies took a long time to emerge, owing to the great difficulty of growing $\mathrm{HCV}$ in cell culture. To circumvent this problem, initial assays for neutralizing HCV antibodies first became feasible through the successful production of HCV/HIV pseudoparticles (HCVpp) able to infect human hepatoma cell lines (Bartosch et al. 2003; Hsu et al. 2003). Later, the laboratory of Takashi Wakita and others developed the first cell culture infectivity system using a genotype 2a cell-cultured virus (HCVcc) able for the first time to undergo the complete virus replication cycle in vitro (Lindenbach et al. 2005; Wakita et al. 2005; Zhong et al. 2005). This still remains the best system for propagating HCV in vitro. Such systems have been used to identify the sequential set of essential cellular receptors required for viral entry as well as the use of the apolipoprotein secretory pathway for $\mathrm{HCV}$ egress from the cell (Scheel and Rice 2013; Paul et al. 2014). Jens Bukh's laboratory then developed chimeric HCVcc's substituting E1E2 genes from many other genotypes, which allowed an assay for cross-neutralizing antibodies against native $\mathrm{HCV}$ infectious virions derived from all the major genotypes (Galli et al. 2013). A highly novel chimeric mouse model for HCV using transplanted human hepatocytes has also been of great value in showing the protective efficacy of passively immunized monoclonal and polyclonal cross-neutralizing antibodies (Mercer et al. 2001; Law et al. 2008; Meuleman et al. 2011; Keck et al. 2016).

Recombinant E1E2 vaccine remains the only $\mathrm{HCV}$ vaccine candidate shown to substantially reduce the chronic carrier rate in vaccinated chimpanzees following experimental challenge with either homologous or heterologous genotype 1a viral strains (Choo et al. 1994; Houghton and Abrignani 2005; Houghton 2011), which predominate in North America and elsewhere. In addition, a vaccine eliciting only cellular immune responses $\left(\mathrm{CD}^{+}\right.$and $\mathrm{CD}^{+}$) against $\mathrm{HCV}$ is in late-stage phase 2 efficacy trials in intravenous drug users in the United States (Swadling et al. 2014). Greater effort and resources need to be applied to vaccine strategies in the future before we can expect to effectively control this global HCV epidemic in high-risk individuals such as intravenous drug users, men who have sex with men, health-care workers frequently exposed to blood, and babies 
born to positive mothers and in developing countries that still experience a high prevalence and incidence of HCV infection.

\section{CONCLUDING REMARKS}

Good progress has been made in preventing hepatitis $\mathrm{C}$ since the discovery of the virus in 1989. We have good diagnostics that have eliminated the threat of posttransfusion $\mathrm{HCV}$ around the world and that are used to monitor eradication of the virus in treated patients. HCV DAAs, which cure most patients independent of HCV genotype within a few months of oral administration and with few side effects, have now supplanted the use of type 1 interferon-based therapies. It will be important in the future to deliver these expensive drugs to all HCV carriers around the globe, which will first require diagnosis of all HCV carriers. Vaccine and immunology research indicate the feasibility of producing at least a partially effective HCV vaccine. Given that the history of infectious disease has taught us the crucial need for an effective vaccine in controlling global epidemics like HCV, it will be very important to deliver a global HCV vaccine in the future.

\section{REFERENCES}

Alter HJ. 1980. The dominant role of non-A, non-B in the pathogenesis of post-transfusion hepatitis: A clinical assessment. Clin Gastroenterol 9: 155-170.

Bankwitz D, Doepke M, Hueging K, Weller R, Bruening J, Behrendt P, Lee JY, Vondran FWR, Manns MP, Bartenschlager R, et al. 2017. Maturation of secreted HCV particles by incorporation of secreted ApoE protects from antibodies by enhancing infectivity. J Hepatol 67: 480489. doi:10.1016/j.jhep.2017.04.010.

Barré-Sinoussi F, Chermann JC, Rey F, Nugeyre MT, Chamaret S, Gruest J, Dauguet C, Axler-Blin C, Vézinet-Brun F, Rouzioux C, et al. 1983. Isolation of a T-lymphotropic retrovirus from a patient at risk for acquired immune deficiency syndrome (AIDS). Science 220: 868-871. doi:10.1126/science.6189183

Bartosch B, Dubuisson J, Cosset FL. 2003. Infectious hepatitis $\mathrm{C}$ virus pseudo-particles containing functional E1E2 envelope protein complexes. J Exp Med 197: 633-642. doi:10.1084/jem.20021756

Bartosch B, Verney G, Dreux M, Donot P, Morice Y, Penin F, Pawlotsky JM, Lavillette D, Cosset FL. 2005. An interplay between hypervariable region 1 of the hepatitis C virus E2 glycoprotein, the scavenger receptor $\mathrm{BI}$, and high-density lipoprotein promotes both enhancement of infection and protection against neutralizing antibodies. J Virol 79: 8217-8229. doi:10.1128/JVI.79.13.8217-8229.2005

Bayer ME, Blumberg BS, Werner B. 1968. Particles associated with Australia antigen in the sera of patients with leukaemia, Down's syndrome and hepatitis. Nature 218: 1057-1059. doi:10.1038/2181057a0

Blight KJ, Kolykhalov AA, Rice CM. 2000. Efficient initiation of HCV RNA replication in cell culture. Science 290: 1972-1974. doi:10.1126/science.290.5498.1972

Bradley DW, Cook EH, Maynard JE, McCaustland KA, Ebert JW, Dolana GH, Petzel RA, Kantor RJ, Heilbrunn A, Fields HA, et al. 1979. Experimental infection of chimpanzees with antihemophilic (factor VIII) materials: Recovery of virus-like particles associated with non-A, non-B hepatitis. J Med Virol 3: 253-269. doi:10.1002/ jmv.1890030403

Chien DY, Choo QL, Ralston R, Spaete R, Tong M, Houghton M, Kuo G. 1993. Persistence of HCV despite antibodies to both putative envelope glycoproteins. Lancet 342: 933. doi:10.1016/0140-6736(93)91983-S

Choo QL, Kuo G, Weiner AJ, Overby LR, Bradley DW, Houghton M. 1989. Isolation of a cDNA clone derived from a blood-borne non-A, non-B viral hepatitis genome. Science 244: 359-362. doi:10.1126/science. 2523562

Choo QL, Richman KH, Han JH, Berger K, Lee C, Dong C, Gallegos C, Coit D, Medina-Selby R, Barr PJ, et al. 1991. Genetic organization and diversity of the hepatitis $C$ virus. Proc Natl Acad Sci 88: 2451-2455. doi:10.1073/pnas 88.6.2451

Choo QL, Kuo G, Ralston R, Weiner A, Chien D, Van Nest G, Han J, Berger K, Thudium K, Kuo C, et al. 1994. Vaccination of chimpanzees against infection by the hepatitis C virus. Proc Natl Acad Sci 91: 1294-1298. doi:10 $.1073 /$ pnas.91.4.1294

Christiansen D, Earnest-Silveira L, Chua B, Meuleman P, Boo I, Grubor-Bauk B, Jackson DC, Keck ZY, Foung SKH, Drummer HE, et al. 2018. Immunological responses following administration of a genotype 1a/1b/2/3a quadrivalent HCV VLP vaccine. Sci Rep 8: 6483. doi:10.1038/s41598-018-24762-9.

Cooper S, Erickson AL, Adams EJ, Kansopon J, Weiner AJ, Chien DY, Houghton M, Parham P, Walker CM. 1999. Analysis of a successful immune response against hepatitis C virus. Immunity 10: 439-449. doi:10.1016/S10747613(00)80044-8

de Leuw P, Stephan C. 2018. Protease inhibitor therapy for hepatitis C virus-infection. Expert Opin Pharmacother 19: 577-587. doi:10.1080/14656566.2018.1454428.

Dreux M, Pietschmann T, Granier C, Voisset C, RicardBlum S, Mangeot PE, Keck Z, Foung S, Vu-Dac N, Dubuisson J, et al. 2006. High density lipoprotein inhibits hepatitis $\mathrm{C}$ virus-neutralizing antibodies by stimulating cell entry via activation of the scavenger receptor BI. J Biol Chem 281: 18285-18295. doi:10.1074/jbc.M60 2706200

Feinstone SM, Kapikian AZ, Purcell RH. 1973. Hepatitis A: Detection by immune electron microscopy of a viruslike antigen associated with acute illness. Science 182: 10261028. doi:10.1126/science.182.4116.1026

Feinstone SM, Kapikian AZ, Purcell RH, Alter HJ, Holland PV. 1975. Transfusion-associated hepatitis not due to vi- 
M. Houghton

ral hepatitis type A or B. N Engl J Med 292: 767-770. doi:10.1056/NEJM197504102921502

Feinstone SM, Alter HJ, Dienes HP, Shimizu Y, Popper H, Blackmore D, Sly D, London WT, Purcell RH. 1981. NonA, non-B hepatitis in chimpanzees and marmosets. J Infect Dis 144: 588-598. doi:10.1093/infdis/144.6.588

Fuller MJ, Callendret B, Zhu B, Freeman GJ, Hasselschwert DL, Satterfield W, Sharpe AH, Dustin LB, Rice CM, Gra koui $\mathrm{A}$, et al. 2013. Immunotherapy of chronic hepatitis $\mathrm{C}$ virus infection with antibodies against programmed cell death-1 (PD-1). Proc Natl Acad Sci 110: 15001-15006. doi:10.1073/pnas.1312772110.

Galli A, Scheel TK, Prentoe JC, Mikkelsen LS, Gottwein JM, Bukh J. 2013. Analysis of hepatitis C virus core/NS5A protein co-localization using novel cell culture systems expressing core-NS2 and NS5A of genotypes 1-7. J Gen Virol 94: 2221-2235. doi:10.1099/vir.0.053868-0.

Gane EJ, Stedman CA, Hyland RH, Ding X, Svarovskaia E, Subramanian GM, Symonds WT, McHutchison JG, Pang PS. 2014. Efficacy of nucleotide polymerase inhibitor sofosbuvir plus the NS5A inhibitor ledipasvir or the NS5B non-nucleoside inhibitor GS-9669 against HCV genotype 1 infection. Gastroenterology 146: 736-743.e1. doi:10 .1053/j.gastro.2013.11.007.

Garrone P, Fluckiger AC, Mangeot PE, Gauthier E, Dupeyrot-Lacas $\mathrm{P}$, Mancip J, Cangialosi A, Du Chéné I, LeGrand R, Mangeot I, et al. 2011. A prime-boost strategy using virus-like particles pseudotyped for $\mathrm{HCV}$ proteins triggers broadly neutralizing antibodies in macaques. Sci Transl Med 3: 94ra71. doi:10.1126/scitranslmed.3002330.

Gerlach JT, Diepolder HM, Jung MC, Gruener NH, Schraut WW, Zachoval R, Hoffmann R, Schirren CA, Santantonio T, Pape GR. 1999. Recurrence of hepatitis C virus after loss of virus-specific $\mathrm{CD} 4{ }^{+} \mathrm{T}$-cell response in acute hepatitis C. Gastroenterology 117: 933-941. doi:10.1016/ S0016-5085(99)70353-7

Grakoui A, Shoukry NH, Woollard DJ, Han JH, Hanson HL, Ghrayeb J, Murthy KK, Rice CM, Walker CM. 2003. HCV persistence and immune evasion in the absence of memory T cell help. Science 302: 659-662. doi:10.1126/science .1088774

Hollinger FB, Mosley JW, Szmuness W, Aach RD, Peters RL, Stevens C. 1980. Transfusion-transmitted viruses study: Experimental evidence for two non-A, non-B, hepatitis agents. J Infect Dis 142: 400-407. doi:10.1093/infdis/142 .3 .400

Houghton M. 2011. Prospects for prophylactic and therapeutic vaccines against the hepatitis $\mathrm{C}$ viruses. Immunol Rev 239: 99-108. doi:10.1111/j.1600-065X.2010.00977.x.

Houghton M, Abrignani S. 2005. Prospects for a vaccine against the hepatitis C virus. Nature 436: 961-966. doi:10.1038/nature04081

Hsu M, Zhang J, Flint M, Logvinoff C, Cheng-Mayer C, Rice CM, McKeating JA. 2003. Hepatitis C virus glycoproteins mediate $\mathrm{pH}$-dependent cell entry of pseudotyped retroviral particles. Proc Natl Acad Sci 100: 7271-7276. doi:10 $.1073 /$ pnas. 0832180100

Keck ZY, Wang Y, Lau P, Lund G, Rangarajan S, Fauvelle C, Liao GC, Holtsberg FW, Warfield KL, Aman MJ, et al 2016. Affinity maturation of a broadly neutralizing human monoclonal antibody that prevents acute hepatitis $\mathrm{C}$ virus infection in mice. Hepatology 64: 1922-1933. doi:10 .1002/hep. 28850

Kuo G, Choo QL, Alter HJ, Gitnick GL, Redeker AG, Purcell RH, Miyamura T, Dienstag JL, Alter MJ, Stevens CE, et al. 1989. An assay for circulating antibodies to a major etiologic virus of human non-A, non-B hepatitis. Science 244: 362-364. doi:10.1126/science. 2496467

Lanford RE, Guerra B, Chavez D, Bigger C, Brasky KM, Wang XH, Ray SC, Thomas DL. 2004. Cross-genotype immunity to hepatitis C virus. J Virol 78: 1575-1581. doi:10.1128/JVI.78.3.1575-1581.2004

Lavillette D, Morice Y, Germanidis G, Donot P, Soulier A, Pagkalos E, Sakellariou G, Intrator L, Bartosch B, Pawlotsky JM, et al. 2005. Human serum facilitates hepatitis C virus infection, and neutralizing responses inversely correlate with viral replication kinetics at the acute phase of hepatitis C virus infection. J Virol 79: 6023-6034. doi:10 .1128/JVI.79.10.6023-6034.2005

Law M, Maruyama T, Lewis J, Giang E, Tarr AW, Stamataki Z, Gastaminza P, Chisari FV, Jones IM, Fox RI, et al. 2008. Broadly neutralizing antibodies protect against hepatitis C virus quasispecies challenge. Nat Med 14: 25-27. doi:10 $1038 / \mathrm{nm} 1698$

Law JL, Chen C, Wong J, Hockman D, Santer DM, Frey SE, Belshe RB, Wakita T, Bukh J, Jones CT, et al. 2013. A hepatitis $\mathrm{C}$ virus (HCV) vaccine comprising envelope glycoproteins gpE1/gpE2 derived from a single isolate elicits broad cross-genotype neutralizing antibodies in humans. PLoS ONE 8: e59776. doi:10.1371/journal .pone.0059776.

Lemm JA, Leet JE, O’Boyle DR II, Romine JL, Huang XS, Schroeder DR, Alberts J, Cantone JL, Sun JH, Nower PT, et al. 2011. Discovery of potent hepatitis C virus NS5A inhibitors with dimeric structures. Antimicrob Agents Chemother 55: 3795-802. doi:10.1128/AAC.00146-11.

Lindenbach BD, Evans MJ, Syder AJ, Wölk B, Tellinghuisen TL, Liu CC, Maruyama T, Hynes RO, Burton DR, McKeating JA, et al. 2005. Complete replication of hepatitis C virus in cell culture. Science 309: 623-626. doi:10 $.1126 /$ science. 1114016

Logvinoff C, Major ME, Oldach D, Heyward S, Talal A, Balfe P, Feinstone SM, Alter H, Rice CM, McKeating JA. 2004. Neutralizing antibody response during acute and chronic hepatitis C virus infection. Proc Natl Acad Sci 101: 1014910154. doi:10.1073/pnas.0403519101

Lohmann V, Körner F, Koch J, Herian U, Theilmann L, Bartenschlager R. 1999. Replication of subgenomic hepatitis C virus RNAs in a hepatoma cell line. Science 285: 110-113. doi:10.1126/science.285.5424.110

McHutchison JG, Lawitz EJ, Shiffman ML, Muir AJ, Galler GW, McCone J, Nyberg LM, Lee WM, Ghalib RH, Schiff ER, et al. 2009. Peginterferon $\alpha$-2b or $\alpha$-2a with ribavirin for treatment of hepatitis C infection. $N$ Engl J Med 361: 580-593. doi:10.1056/NEJMoa0808010.

Mehta SH, Cox A, Hoover DR, Wang XH, Mao Q, Ray S, Strathdee SA, Vlahov D, Thomas DL. 2002. Protection against persistence of hepatitis C. Lancet 359: 14781483. doi:10.1016/S0140-6736(02)08435-0

Mercer DF, Schiller DE, Elliott JF, Douglas DN, Hao C, Rinfret A, Addison WR, Fischer KP, Churchill TA, Lakey JR, et al. 2001. Hepatitis $C$ virus replication in mice with 
chimeric human livers. Nat Med 7: 927-933. doi:10.1038/ 90968

Meuleman P, Bukh J, Verhoye L, Farhoudi A, Vanwolleghem T, Wang RY, Desombere I, Alter H, Purcell RH, LerouxRoels G. 2011. In vivo evaluation of the cross-genotype neutralizing activity of polyclonal antibodies against hepatitis C virus. Hepatology 53: 755-762. doi:10.1002/hep .24171 .

Meunier JC, Engle RE, Faulk K, Zhao M, Bartosch B, Alter H, Emerson SU, Cosset FL, Purcell RH, Bukh J. 2005. Evidence for cross-genotype neutralization of hepatitis $C$ virus pseudo-particles and enhancement of infectivity by apolipoprotein C1. Proc Natl Acad Sci 102: 4560 4565. doi:10.1073/pnas.0501275102

Meunier JC, Gottwein JM, Houghton M, Russell RS, Emerson SU, Bukh J, Purcell RH. 2011. Vaccine-induced crossgenotype reactive neutralizing antibodies against hepatitis C virus. J Infect Dis 204: 1186-1190. doi:10.1093/infdis/ jir511.

Morin TJ, Broering TJ, Leav BA, Blair BM, Rowley KJ, Boucher EN, Wang Y, Cheslock PS, Knauber M, Olsen DB, et al. 2012. Human monoclonal antibody HCV1 effectively prevents and treats HCV infection in chimpanzees. PLoS Pathog 8: e1002895. doi:10.1371/journal.ppat.1002895.

Paul D, Madan V, Bartenschlager R. 2014. Hepatitis C virus RNA replication and assembly: Living on the fat of the land. Cell Host Microbe 16: 569-579. doi:10.1016/j.chom .2014.10.008

Pestka JM, Zeisel MB, Bläser E, Schürmann P, Bartosch B, Cosset FL, Patel AH, Meisel H, Baumert J, Viazov S, et al. 2007. Rapid induction of virus-neutralizing antibodies and viral clearance in a single-source outbreak of hepatitis C. Proc Natl Acad Sci 104: 6025-6030. doi:10.1073/pnas .0607026104

Prince AM, Brotman B, Grady GF, Kuhns WJ, Hazzi C, Levine RW, Millian SJ. 1974. Long-incubation post-transfusion hepatitis without serological evidence of exposure to hepatitis-B virus. Lancet 304: 241-246. doi:10.1016/ S0140-6736(74)91412-3

Scheel TK, Rice CM. 2013. Understanding the hepatitis C virus life cycle paves the way for highly effective therapies. Nat Med 19: 837-849. doi:10.1038/nm.3248.

Shoukry NH, Grakoui A, Houghton M, Chien DY, Ghrayeb J, Reimann KA, Walker CM. 2003. Memory CD8 ${ }^{+}$T cells are required for protection from persistent hepatitis $\mathrm{C}$ virus infection. J Exp Med 197: 1645-1655. doi:10.1084/ jem.20030239

Sofia MJ, Bao D, Chang W, Du J, Nagarathnam D, Rachakonda S, Reddy PG, Ross BS, Wang P, Zhang HR, et al 2010. Discovery of a $\beta-\mathrm{d}-2^{\prime}$-deoxy- $2^{\prime}-\alpha$-fluoro- $2^{\prime}-\beta$-Cmethyluridine nucleotide prodrug (PSI-7977) for the treatment of hepatitis C virus. J Med Chem 53: 72027218. doi:10.1021/jm100863x.

Stamataki Z, Coates S, Evans MJ, Wininger M, Crawford K, Dong C, Fong YL, Chien D, Abrignani S, Balfe P, et al. 2007. Hepatitis C virus envelope glycoprotein immunization of rodents elicits cross-reactive neutralizing antibodies. Vaccine 25: 7773-7784. doi:10.1016/j.vaccine.2007.08 .053
Hepatitis C Virus: 30 Years after Discovery

Swadling L, Capone S, Antrobus RD, Brown A, Richardson R, Newell EW, Halliday J, Kelly C, Bowen D, Fergusson J, et al. 2014. A human vaccine strategy based on chimpanzee adenoviral and MVA vectors that primes, boosts, and sustains functional HCV-specific T cell memory. Sci Transl Med 6: 261ra153. doi:10.1126/scitranslmed .3009185.

Vietheer PT, Boo I, Gu J, McCaffrey K, Edwards S, Owczarek C, Hardy MP, Fabri L, Center RJ, Poumbourios P, et al. 2017. The core domain of hepatitis $C$ virus glycoprotein $\mathrm{E} 2$ generates potent cross-neutralizing antibodies in guinea pigs. Hepatology 65: 1117-1131. doi:10.1002/hep .28989 .

Voisset C, Op de eeck A, Horellou P, Dreux M, Gustot T, Duverlie G, Cosset FL, Vu-Dac N, Dubuisson J. 2006. High-density lipoproteins reduce the neutralizing effect of hepatitis $\mathrm{C}$ virus (HCV)-infected patient antibodies by promoting HCV entry. J Gen Virol 87: 2577-2581. doi:10 $.1099 /$ vir.0.81932-0

Wakita T, Pietschmann T, Kato T, Date T, Miyamoto M, Zhao Z, Murthy K, Habermann A, Kräusslich HG, Mizokami M, et al. 2005. Production of infectious hepatitis C virus in tissue culture from a cloned viral genome. Nat Med 11: 791-796. Erratum in Nat Med 11: 905 (2005). doi:10.1038/nm1268

Wang X, Yan Y, Gan T, Yang X, Li D, Zhou D, Sun Q, Huang Z, Zhong J. 2019. A trivalent HCV vaccine elicits broad and synergistic polyclonal antibody response in mice and rhesus monkey. Gut 68: 140-149. doi:10.1136/gutjnl2017-314870.

Weiner AJ, Paliard X, Selby MJ, Medina-Selby A, Coit D, Nguyen S, Kansopon J, Arian CL, Ng P, Tucker J, et al. 2001. Intrahepatic genetic inoculation of hepatitis $C$ virus RNA confers cross-protective immunity. J Virol 75: 7142-7148. doi:10.1128/JVI.75.15.7142-7148.2001

Weisberg IS, Jacobson IM. 2017. A pangenotypic, single tablet regimen of sofosbuvir/velpatasvir for the treatment of chronic hepatitis C infection. Expert Opin Pharmacother 18: 535-543. doi:10.1080/14656566.2017.1282459.

Wong JA, Bhat R, Hockman D, Logan M, Chen C, Levin A, Frey SE, Belshe RB, Tyrrell DL, Law JL, et al. 2014. Recombinant hepatitis $\mathrm{C}$ virus envelope glycoprotein vaccine elicits antibodies targeting multiple epitopes on the envelope glycoproteins associated with broad cross-neutralization. J Virol 88: 14278-14288. doi:10.1128/JVI .01911-14.

Yang Z, Wang X, Chi X, Zhao F, Guo J, Ma P, Zhong J, Niu J, Pan X, Long G. 2016. Neglected but important role of apolipoprotein $\mathrm{E}$ exchange in hepatitis $\mathrm{C}$ virus infection. J Virol 90: 9632-9643. doi:10.1128/JVI.01353-16

Young RA, Davis RW. 1983. Efficient isolation of genes by using antibody probes. Proc Natl Acad Sci 80: 1194-1198. doi:10.1073/pnas.80.5.1194

Zhong J, Gastaminza P, Cheng G, Kapadia S, Kato T, Burton DR, Wieland SF, Uprichard SL, Wakita T, Chisari FV. 2005. Robust hepatitis C virus infection in vitro. Proc Natl Acad Sci 102: 9294-9299. doi:10.1073/pnas .0503596102 


\section{$\&_{\mathrm{CSH}}^{\infty} \&$ Cold Spring Harbor

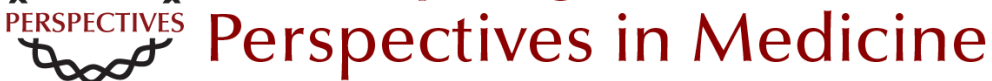

\section{Hepatitis C Virus: 30 Years after Its Discovery}

Michael Houghton

Cold Spring Harb Perspect Med 2019; doi: 10.1101/cshperspect.a037069 originally published online September 9, 2019

\section{Subject Collection Hepatitis C Virus: The Story of a Scientific and Therapeutic Revolution}

Antibody Responses in Hepatitis C Infection Mansun Law

T-Cell Immunity against the Hepatitis C Virus: A Persistent Research Priority in an Era of Highly Effective Therapy

Stephanie Smith, Jonathan R. Honegger and Christopher Walker

Interferon-Free Hepatitis C Virus Therapy Jean-Michel Pawlotsky

Animal Models of Hepatitis C Virus Infection Alexander Ploss and Amit Kapoor

Natural History of Hepatic and Extrahepatic Hepatitis C Virus Diseases and Impact of Interferon-Free HCV Therapy Francesco Negro

Hepatitis C Virus Epidemiology and the Impact of Interferon-Free Hepatitis C Virus Therapy Jeffrey V. Lazarus, Elena Roel and Ahmed M. Elsharkawy

Hepatitis C Virus Entry: Protein Interactions and Fusion Determinants Governing Productive Hepatocyte Invasion

Gisa Gerold, Rebecca Moeller and Thomas Pietschmann

Hepatitis C Virus Structure: Defined by What It Is Not

Altaira D. Dearborn and Joseph Marcotrigiano
Innate Immunity in Hepatitis C Virus Infection Johannes Schwerk, Amina Negash, Ram Savan, et al.

HCV Assembly and Egress via Modifications in Host Lipid Metabolic Systems Kunitada Shimotohno

Control of HCV Infection by Natural Killer Cells and Macrophages

Hugo R. Rosen and Lucy Golden-Mason

The Elimination of Hepatitis $\mathbf{C}$ as a Public Health

Threat Margaret Hellard, Sophia E. Schroeder, Alisa Pedrana, et al.

Hepatitis C Virus Replication Keisuke Tabata, Christopher J. Neufeldt and Ralf Bartenschlager

Challenges and Promise of a Hepatitis $\mathbf{C}$ Virus Vaccine Andrea L. Cox

Rewiring Host Signaling: Hepatitis C Virus in Liver Pathogenesis

Alessia Virzì, Armando Andres Roca Suarez, Thomas F. Baumert, et al.

Hepatitis C Virus: $\mathbf{3 0}$ Years after Its Discovery Michael Houghton

For additional articles in this collection, see http://perspectivesinmedicine.cshlp.org/cgi/collection/ 